\title{
Workplace violence among health-care workers in emergency departments of public hospitals in Dammam, Saudi Arabia
}

Moussa Harthi, ${ }^{1}$ Mohammed Olayan, ${ }^{1}$ Hassan Abugad ${ }^{1}$ and Moataza Abdel Wahab ${ }^{1}$

${ }^{1}$ Department of Family and Community Medicine, Imam Abdulrahman Bin Faisal University, Dammam, Saudi Arabia. (Correspondence to: M.M. Harthi: dr_mmh@hotmail.com).

\begin{abstract}
Background: Workplace violence is a serious occupational health problem. Emergency health-care workers have a high risk of exposure to violence with negative personal consequences.

Aims: To estimate the prevalence and possible associated factors of workplace violence among health-care workers in emergency departments of public hospitals in Dammam, Saudi Arabia.

Methods: A cross-sectional study was conducted during August to October 2018 at 4 emergency departments of public hospitals belonging to the Saudi Ministry of Health. Data were collected using a self-administered questionnaire.

Results: Of 380 questionnaires distributed, 324 were returned ( $85 \%$ response rate). Almost two thirds of the participants were women $(66.4 \%)$ and more than half $(54 \%)$ were nurses. A total of 155 health-care workers $(47.8 \%)$ had experienced at least 1 type of violent incident in the preceding 12 months. Of the total violence incidents, $52 \%$ were verbal abuse, 19\% were physical violence, and sexual harassment (3\%) was the least common. Lack of encouragement to report incidents and Saudi nationality were the only significant variables associated with workplace violence.
\end{abstract}

Conclusions: Workplace violence was prevalent, and verbal abuse was the commonest type among health-care workers in emergency departments of Saudi hospitals. Encouragement to report violent incidents and raising awareness among health-care workers about violence reporting systems are important strategies to improve workplace safety.

Keywords: emergency departments, healthcare workers, Saudi Arabia, reporting, workplace violence

Citation: Harthi M; Olayan M; Abugad H; Abdel Wahab M. Workplace violence among health-care workers in emergency departments of public hospitals in Dammam, Saudi Arabia. East Mediterr Health J. 2020;26(12):1473-1481. https://doi.org/10.26719/emhj.20.069

Received: 30/05/19; accepted: 19/11/19

Copyright (C) World Health Organization (WHO) 2020. Open Access. Some rights reserved. This work is available under the CC BY-NC-SA 3.0 IGO license (https://creativecommons.org/licenses/by-nc-sa/3.o/igo).

\section{Introduction}

Health care workers (HCWs) are among the groups most experiencing violence and aggressive behaviour at work, especially those who work in emergency departments (EDs) in public hospitals (1). Workplace violence has negative consequences on safety and workplace activities of HCWs (2). However, the estimated prevalence of violence against HCWs is still unknown because there is no clear definition of a violent incident $(1,2)$. The World Health Organization (WHO) defined violence as "The intentional use of physical force or power, threatened or actual, against another person or against oneself or a group of people that results in or has a high likelihood of resulting in injury, death, psychological harm, maldevelopment or deprivation" (3). The National Institute for Occupational Safety and Health defines workplace violence as "violent acts (including physical assault and threats of assault) directed towards persons at work or on duty" (4). According to WHO, physical or psychological violence can appear in different forms, which may often overlap $(4,5)$. Physical violence is defined as the use of physical force against another person or group that results in physical, sexual or psychological harm, and such violence includes beating, kicking, slapping, stabbing, shooting, pushing, biting and pinching $(3,5)$. Psychological violence is defined as intentional use of power, including threat of physical force, against another person or group that can result in harm to physical, mental, spiritual, moral or social development. Psychological violence includes verbal abuse, bullying/mobbing, harassment (including sexual and racial) and threats.

Many studies worldwide have examined the prevalence of workplace violence among HCWs (2). A survey of workplace violence across 65 American EDs conducted in 2008 showed that the violence and weapons in the EDs were common, and nurses were less likely to feel safe than other staff were (6). A cross-sectional study in 2009 in Tokyo, Japan revealed that $36.4 \%$ of 11095 HCWs in 19 hospitals experienced workplace violence by patients or their relatives; $15.9 \%$ experienced physical aggression, 29.8\% experienced verbal abuse and $9.9 \%$ experienced sexual harassment (7). In another large study conducted between October 2012 and July 2013 at primary healthcare centres in Belgrade, Serbia, the prevalence of workplace violence was 52.6\% among 1757 HCWs (8). In the Middle East, workplace violence has been investigated in several studies. An Iranian cross-sectional survey in 2011 among 196 nurses in 11 EDs in teaching hospitals in Tehran, showed that 19.7\% of nurses faced physical violence and 91.6\% experienced verbal abuse (9). Another cross-sectional study in Jordan in 2011 among 227 nurses in 12 provinces revealed that 
$75.8 \%$ were exposed to at least 1 type of violence (10). A comprehensive survey of workplace violence among 713 physicians in EDs in Turkey found that $78.1 \%$ had experienced violence (11). Factors related to the increased the risk of workplace violence are related to the offenders, HCWs or the workplace environment (2). Personality and mental health disorders (such as schizophrenia, paranoia, anxiety, antisocial attitude, dementia and alcohol abuse) are the most significant factors related to the offenders (7). HCW-related factors include understaffed working conditions, working alone and long working hours ( 7 , 12). Factors related to the workplace include long waiting times, overcrowding, inadequate security, and lack of policies for preventing violence (12). In a few studies in Saudi Arabia, there was difficultly in estimating the magnitude of the problem due to lack of reporting and other factors $(2,13)$. In 2009, a self-reporting questionnaire study in $\mathrm{Al}$-Hassa of 1091 primary health care professionals revealed that $28 \%$ suffered from workplace violence (12). A cross-sectional study in Riyadh in 2011 of 600 physicians and nurses found that $67.4 \%$ were exposed to workplace violence, and that nurses were more susceptible than physicians (14). In another cross-sectional study in 2014 in 12 family medical centres in Riyadh, $45.6 \%$ of 270 HCWs experienced some sort of violence during the 12 months prior to the study (2). Three studies were conducted in Saudi Arabia in 2015. A cross-sectional study at King Fahd Hospital showed that $30.7 \%$ of 391 nurses were exposed to verbal abuse (13). In EDs of 3 hospitals in Riyadh, $89.3 \%$ of 121 nurses experienced a violent incident in the 12 months prior to the study (15). In EDs in Tabuk, 90.7\% of 129 had history of workplace violence (1). EDs are in operation 24 hours a day, 7 days a week (16). Patients usually come to EDs with relatives or friends with expectations of a rapid response and good service from HCWs regardless of the severity of the case (12). EDs receive a huge number of patients, therefore, the chance of HCWs being exposed to violence is high $(1,12)$.

This study was conducted to estimate the prevalence of workplace violence among HCWs in EDs in public hospitals in Dammam, Saudi Arabia and to determine possible associated factors.

\section{Methods}

This was a cross-sectional survey conducted during August to October 2018 at 4 public hospitals belonging to the Ministry of Health in Dammam, Saudi Arabia: Dammam General Medical Complex, Dhahran Eye Specialist Hospital, Maternal and Children's Hospital and Al-Amal Complex for Mental Health). All HCWs in all duty shifts (morning, evening and night) in EDs were invited to participate, with exclusion of those with work experience < 1 year. The sample size was calculated using epi info, assuming the level of violence among HCWs was $89 \%$ from previous data (15), with an accepted margin of error $4 \%$. The sample by population survey was 235 HCWs at $95 \%$ confidence level and was increased to 294 HCWs, expecting $80 \%$ response.

Data were collected from 324 participants, using a self-administered questionnaire that was based on questionnaires developed by WHO (5) and was modified by the researchers. The English language questionnaire was translated into Arabic by the authors and validated by 3 experts in the Department of Family and Community Medicine, Imam Abdulrahman Bin Faisal University. The questionnaire consisted of 8 sections. The first part included demographic information such as age, sex, marital status, occupational title, nationality, educational level, and years of work experience. The second part consisted of items that addressed occupational characteristics (working multiple shifts, shift time worked, number of coworkers in the same work area, encouragement to report violent events, and availability of a violence reporting system). The other sections consisted of items that addressed the characteristics of the violent acts experienced (time, place and frequency of violence) and the identity, age and sex of the offender. There were also questions about reasons for violence (e.g., lack of security and absence of punishment) and the consequences for the HCWs and the offenders. Finally, there was a question about reasons for not reporting acts of violence. Types of violence were classified into physical, verbal, bullying, and sexual and racial harassment (5). A pilot study was carried out on 10 HCWs in 1 public hospital on 1 day, to check the clarity of the language used and estimate the average time to answer the questionnaire. The participants in the pilot study were not included in the present study.

All statistical analyses were conducted using SPSS version 25, setting our level of confidence at $95 \%$. Descriptive statistics by frequency and percentage were used for categorical variables, while continuous variables were assessed for normality. The frequency of workplace violence was calculated by dividing the number of those who had experienced violence during the preceding 12 months by the total number of HCWs in the study. The $\mathrm{c} 2$ and independent samples $t$ test were used to assess the relation between demographic and occupational characteristics and workplace violence. Logistic regression analysis was used to assess factors independently associated with the occurrence of workplace violence. Adjusted odds ratios with corresponding $95 \%$ confidence intervals were presented.

\section{Results}

\section{Demographic and occupational characteristics}

Of 380 questionnaires distributed, 324 were returned ( $85 \%$ response rate). The age of participants ranged between 22 and 55 years, with a mean of 32.7 (standard deviation, 6.2) years, and 215 were women $(66.4 \%$ ) (Table 1). The majority (78.1\%) of HCWs were Saudis and almost two thirds were married. The largest proportion had a diploma (50.3\%) followed by a bachelor's degree (43.5\%). More than half the HCWs $(54 \%)$ were nurses and $40.1 \%$ had work experience of 6-9 years.

\section{Report encouragement and system availability}

One hundred and ninety-three (59.6\%) of 324 respondents 


\begin{tabular}{|c|c|c|}
\hline Health-care worker characteristics & No. & $\%$ \\
\hline Occupation & & \\
\hline Physician & 63 & 19 \\
\hline Nurse & 175 & 54 \\
\hline Others $^{\mathrm{a}}$ & 86 & 27 \\
\hline Sex & & \\
\hline Male & 109 & 33.6 \\
\hline Female & 215 & 66.4 \\
\hline Age $(y r)^{b}$ & & \\
\hline$\leq 30$ & 153 & 47.2 \\
\hline $31-40$ & 136 & 42 \\
\hline$>40$ & 35 & 10.8 \\
\hline Marital status & & \\
\hline Married & 226 & 69.8 \\
\hline Unmarried & 98 & 30.2 \\
\hline Nationality & & \\
\hline Saudi & 253 & 78.1 \\
\hline Non-Saudi & 71 & 21.9 \\
\hline Education & & \\
\hline Diploma & 163 & 50.3 \\
\hline Bachelor's & 141 & 43.5 \\
\hline Master's & 12 & 3.7 \\
\hline Board ${ }^{c}$ & 8 & 2.5 \\
\hline Work experience (yr) & & \\
\hline $1-5$ & 126 & 38.9 \\
\hline $6-9$ & 130 & 40.1 \\
\hline$>10$ & 68 & 21 \\
\hline Multiple shifts & & \\
\hline Yes & 292 & 90.1 \\
\hline No & 32 & 9.9 \\
\hline Shift time & & \\
\hline Morning & 42 & 13 \\
\hline Alternate & 282 & 87 \\
\hline No. of coworkers & & \\
\hline Mean (standard deviation) & $9(5)$ & \\
\hline$\leq 10$ & 232 & 71.6 \\
\hline$>10$ & 92 & 28.4 \\
\hline
\end{tabular}

aPharmacists, technicians and clerical workers.

${ }^{b}$ Mean age 32.7 (6.2) years.

'Medical degree for physicians to receive privileges and to practice medicine in a particular field.

stated that they were encouraged to report workplace violence and 131 (40.4\%) that they were not encouraged. Two hundred and twenty-five (69.4\%) HCWs reported that a system was available for reporting violence and 99 $(30.6 \%)$ reported no such system.

\section{Frequency and type of violent incident}

Out of 324 HCWs, 155 (47.8 \%) had experienced at least 1 type of violent incident during the preceding 12 months. Among 241 incidents, 126 (52\%) were verbal abuse, 45 (19\%) physical violence, 39 (16\%) bullying, 24 (10\%) racial harassment and 7 (3\%) sexual harassment (Table 2). Ninety-five (39.4\%) violent incidents happened in the morning and the same number in the evening. Almost all $(n=232$, 96.3\%) of the violent incidents occurred in the workplace. Ninety-nine (41.1\%) violent incidents occurred once a year and $73(30.3 \%)$ more than once a month. Most ( $n=102$, $42 \%$ ) of the offenders were patients, followed by relatives of patients ( $n=75,31 \%$ ). The majority $(n=197,82 \%)$ of the offenders were aged $21-45$ years and 41 (17\%) were $\geq 46$ years. Both men and women committed the violent act in $97(40.25 \%)$ cases, men only in 95 (39.42\%) and women only in $49(20.33 \%)$. Most $(n=180,74.7 \%)$ of the participants exposed to violence believed that the incident could have been prevented. The violence incident ended with the following consequences for the offenders: none ( $n=154,63.9 \%)$, verbal warning $(n=51,21.2 \%)$ and reported to the police ( $n=16,6.6 \%$ ). The consequences for HCWs were: none $(n=112,46.5 \%)$, reduced work performance ( $n$ $=107,44.4 \%)$, documented complaint against HCWs $(n=$ $20,8.3 \%$ ) and injuries ( $\mathrm{n}=2,0.8 \%)$. Almost all $(\mathrm{n}=41,91.1 \%)$ incidents of physical violence happened without a weapon and 23 (51.1\%) were committed by men. Most physical ( $n=22,48.9 \%)$ and verbal abuse $(n=55,43.7 \%)$ occurred in the evening. The majority $(n=29,74.4 \%)$ of bullying incidents occurred in the morning and managers were a major source $(n=22,56.4 \%)$ of violent incidents, followed by staff members ( $n=14,35.9 \%)$. In $34(87.2 \%)$ of those incidents, no action was taken. Sexual harassment among staff members was the highest $(n=3,42.9 \%)$. Decline in work performance was reported in 20 (44.4\%) HCWs who experienced physical violence and in 13 (54.2\%) who were subjected to racial harassment.

\section{Factors associated with workplace violence}

HCWs who experienced violence reported that it was caused by absence of punishment (67\%), lack of security (51\%), staff shortage $(34 \%)$, long waiting time for patients (33\%), overcrowding (29\%), personality type (17\%), cultural beliefs ( $9 \%$ ), lack of patient privacy (3\%) and language barrier (2\%). Absence of punishment was the most common cause of verbal abuse (61\%), bullying (95\%), sexual (71\%) and racial (58\%) harassment, whereas, lack of security was the most common cause of physical violence (64\%).

\section{History of workplace violence related to characteristics of health-care workers}

Demographic and occupational features of HCWs who did and did not experience violence are shown in Table 3. Sex was significantly associated with violence, with violence being more frequent for men $(n=63,57.8 \%)$ than women ( $n=92,42.8 \%$ ). Nationality was significantly associated with violence and was more frequent for Saudis ( $n=131,51.8 \%$ ) than non-Saudis $(n=24,33.8 \%)$. Those who worked with $\leq 10$ coworkers $(n=124,53.4 \%)$ reported significantly more frequent violence than those who worked with $>10$ coworkers $(n=31,33.7 \%)$. Those who lacked encouragement to report violent acts $(n=79,60.3 \%$ ) reported significantly more frequent violence than those who had such encouragement ( $n=76,39.4 \%$ ). Those who confirmed lack of availability of a system for reporting violence $(n=57,57.6 \%)$ reported significantly more frequent violence than those who confirmed system availability $(n=98,43.6 \%)$. 


\begin{tabular}{|c|c|c|c|c|c|c|c|c|c|c|c|c|}
\hline \multirow[t]{3}{*}{ Characteristics and types of violence } & \multicolumn{2}{|c|}{ Physical } & \multicolumn{2}{|c|}{ Verbal } & \multicolumn{2}{|c|}{ Bullying } & \multicolumn{2}{|c|}{ Sexual } & \multicolumn{2}{|c|}{ Racial } & \multicolumn{2}{|c|}{ Total } \\
\hline & $n$ & $\%$ & $n$ & $\%$ & $n$ & $\%$ & $n$ & $\%$ & $n$ & $\%$ & $n$ & $\%$ \\
\hline & 45 & 19 & 126 & 52 & 39 & 16 & 7 & 3 & 24 & 10 & 241 & 100 \\
\hline \multicolumn{13}{|l|}{ Shift time } \\
\hline Morning & 10 & 22.2 & 42 & $33 \cdot 3$ & 29 & 74.4 & 3 & 42.9 & 11 & 45.8 & 95 & 39.4 \\
\hline Evening & 22 & 48.9 & 55 & 43.7 & 6 & 15.4 & 3 & 42.9 & 9 & 37.5 & 95 & 39.4 \\
\hline Night & 13 & 28.9 & 29 & 23 & 4 & 10.3 & 1 & 14.3 & 4 & 16.7 & 51 & 21.2 \\
\hline \multicolumn{13}{|l|}{ Location } \\
\hline Inside & 40 & 88.9 & 123 & 97.6 & 38 & 97.4 & 7 & 100 & 24 & 100 & 232 & 96.3 \\
\hline Outside & 0 & 0 & 1 & 0.8 & 1 & 2.6 & 0 & 0 & 0 & 0 & 2 & 0.8 \\
\hline Both & 5 & 11.1 & 2 & 1.6 & 0 & 0 & 0 & 0 & 0 & 0 & 7 & 2.9 \\
\hline \multicolumn{13}{|l|}{ Frequency $^{a}$} \\
\hline Once a year & 24 & 53.3 & 39 & 31 & 21 & 53.8 & 5 & 71.4 & 10 & 41.7 & 99 & 41.1 \\
\hline Once a month & 14 & 31.1 & 39 & 31 & 9 & 23.1 & 0 & 0 & 7 & 29.2 & 69 & 28.6 \\
\hline More than once per month & 7 & 15.6 & 48 & 38 & 9 & 23.1 & 2 & 28.6 & 7 & 29.2 & 73 & 30.3 \\
\hline \multicolumn{13}{|l|}{ Offender identity } \\
\hline Patient / client & 24 & $53 \cdot 3$ & 65 & 51.6 & 0 & 0 & 2 & 28.6 & 11 & 45.8 & 102 & 42 \\
\hline Relatives & 16 & 35.6 & 48 & 38.1 & 0 & 0 & 1 & 14.3 & 10 & 41.7 & 75 & 31.1 \\
\hline Staff memberb & 1 & 2.2 & 5 & 4 & 14 & 35.9 & 3 & 42.9 & 0 & 0 & 23 & 10 \\
\hline Management & 0 & 0 & 1 & 0.8 & 22 & 56.4 & 0 & 0 & 3 & 12.5 & 26 & 10.8 \\
\hline External colleague & 1 & 2.2 & 1 & 0.8 & 3 & 7.7 & 0 & 0 & 0 & 0 & 5 & 2 \\
\hline General public & 3 & 6.7 & 6 & 4.8 & 0 & 0 & 1 & 14.3 & 0 & 0 & 10 & 4.1 \\
\hline \multicolumn{13}{|l|}{ Offender age } \\
\hline$<20$ years & 0 & 0 & 3 & 2.4 & 0 & 0 & 0 & 0 & 0 & 0 & 3 & 1 \\
\hline $21-45$ years & 42 & 93.3 & 100 & 79.4 & 30 & 76.9 & 7 & 100 & 18 & 75 & 197 & 82 \\
\hline$\geq 46$ years & 3 & 6.7 & 23 & 18.3 & 9 & 23.1 & 0 & 0 & 6 & 25 & 41 & 17 \\
\hline \multicolumn{13}{|l|}{ Offender sex ${ }^{a}$} \\
\hline Male & 23 & 51.1 & 40 & 32 & 18 & 46.2 & 5 & 71.4 & 9 & 37.5 & 95 & 39.42 \\
\hline Female & 7 & 15.6 & 24 & 19 & 11 & 28.2 & 2 & 28.6 & 5 & 20.5 & 49 & 20.33 \\
\hline Both & 15 & $33 \cdot 3$ & 62 & 49 & 10 & 25.6 & 0 & 0 & 10 & 41.7 & 97 & 40.25 \\
\hline \multicolumn{13}{|l|}{ Could have been prevented } \\
\hline Yes & 41 & 91.1 & 91 & 72.2 & 28 & 71.8 & 4 & 57.1 & 16 & 66.7 & 180 & 74.7 \\
\hline No & 4 & 8.9 & 35 & 27.8 & 11 & 28.2 & 3 & 42.9 & 8 & 33.3 & 61 & $25 \cdot 3$ \\
\hline \multicolumn{13}{|l|}{ Consequences on attacker } \\
\hline None & 19 & 42.2 & 80 & 63.5 & 34 & 87.2 & 4 & 57.1 & 17 & 70.8 & 154 & 63.9 \\
\hline Verbal warning & 13 & 28.9 & 29 & 23 & 2 & 5.1 & 3 & 42.9 & 4 & 16.7 & 51 & 21.2 \\
\hline Reported to police & 9 & 20 & 7 & 5.6 & 0 & 0 & 0 & 0 & 0 & 0 & 16 & 6.6 \\
\hline Do not know & 4 & 8.9 & 10 & 7.9 & 3 & 7.7 & 0 & 0 & 3 & 12.5 & 20 & 8.3 \\
\hline \multicolumn{13}{|l|}{ Consequences on HCW } \\
\hline None & 16 & 35.6 & 61 & 48.4 & 20 & 51.3 & 5 & 71.4 & 10 & 41.7 & 112 & 46.5 \\
\hline Reduce work performance & 20 & 44.4 & 54 & 42.9 & 18 & 46.2 & 2 & 28.6 & 13 & 54.2 & 107 & 44.4 \\
\hline Incident form against HCWs & 7 & 15.6 & 11 & 8.7 & 1 & 2.6 & 0 & 0 & 1 & 4.2 & 20 & 8.3 \\
\hline Injured & 2 & 4.4 & 0 & 0 & 0 & 0 & 0 & 0 & 0 & 0 & 2 & 0.8 \\
\hline
\end{tabular}

aPercentage calculated from HCWs that could have been subjected to $>1$ incidence of violence. ${ }^{b}$ Physicians, nurses, pharmacists, technicians and clerical workers. $\mathrm{HCW}=$ healthcare worker.

\section{Type of workplace violence related to characteristics of health-care workers}

Men $(n=22,20.2 \%)$ experienced significantly more physical violence than women did $(n=23,10.7 \%)$ (Table 4). Men ( $n=51,46.8 \%$ ) also had significantly more verbal abuse than women had $(n=75,34.9 \%)$. Violence was significantly more frequent for unmarried $(n=5,5.1 \%)$ than married $(n=2,0.9 \%)$ HCWs. Saudi HCWs $(n=106,41.9 \%)$ experienced verbal abuse significantly more often than non-Saudis did $(n=20,28.2 \%)$. Physical violence was significantly more frequent in HCWs with $<10$ coworkers $(n=38,16.4 \%)$ than in those with $>10$ coworkers $(n=7$,
7.6\%). Verbal abuse was also significantly more frequent in HCWs with $<10$ coworkers $(n=101,43.5 \%$ ) than in those with $>10$ coworkers $(n=25,27.2 \%)$. HCWs who lacked encouragement to report violent incidents reported significantly more verbal abuse $(n=65,49.6 \%)$ than those who had encouragement $(n=61,31.6 \%)$. Similarly, HCWs who lacked encouragement to report violence reported significantly more bullying $(n=23,17.6 \%)$ than those who had encouragement $(n=16,8.3 \%)$. In contrast, demographic and occupational characteristics, such as age, occupation, shift time, direct contact with patient, and patient types, were not significantly associated with general or specific types of violence. 


\begin{tabular}{|c|c|c|c|c|c|c|c|c|}
\hline \multirow[t]{3}{*}{ Health-care worker characteristics } & \multicolumn{4}{|c|}{ History of exposure to violence } & \multirow{2}{*}{\multicolumn{2}{|c|}{$\begin{array}{c}\text { Total } \\
324\end{array}$}} & \multirow[t]{3}{*}{ c2 } & \multirow[t]{3}{*}{$\mathbf{P}$} \\
\hline & \multicolumn{2}{|c|}{ Yes } & \multicolumn{2}{|c|}{ No } & & & & \\
\hline & $\mathbf{n}$ & $\%$ & n & $\%$ & $\mathbf{n}$ & $\%$ & & \\
\hline \multicolumn{9}{|l|}{ Sex } \\
\hline Male & 63 & 57.8 & 46 & 42.2 & 109 & 33.6 & \multirow[t]{2}{*}{6.528} & \multirow[t]{2}{*}{0.01} \\
\hline Female & 92 & 42.8 & 123 & 57.2 & 215 & 66.4 & & \\
\hline Age & \multirow{2}{*}{\multicolumn{2}{|c|}{$\begin{array}{c}155 \\
32.5(5.7)\end{array}$}} & 169 & & \multirow{2}{*}{\multicolumn{2}{|c|}{324}} & & \multirow[t]{2}{*}{0.622} \\
\hline Mean (SD) & & & $\begin{array}{l}32.9 \\
(6.6)\end{array}$ & & & & & \\
\hline \multicolumn{9}{|l|}{ Age group, yr } \\
\hline$\leq 30$ & 70 & 45.8 & 83 & 54.2 & 153 & 47.2 & \multirow{3}{*}{2.168} & \multirow{3}{*}{0.338} \\
\hline $31-40$ & 71 & 52.2 & 65 & 47.8 & 136 & 42 & & \\
\hline$>40$ & 14 & 40 & 21 & 60 & 35 & 10.8 & & \\
\hline \multicolumn{9}{|l|}{ Marital status } \\
\hline Married & 109 & 48.2 & 117 & 51.8 & 226 & 69.8 & \multirow[t]{2}{*}{0.046} & \multirow[t]{2}{*}{0.831} \\
\hline Unmarried & 46 & 46.9 & 52 & 53.1 & 98 & 30.2 & & \\
\hline \multicolumn{9}{|l|}{ Nationality } \\
\hline Saudi & 131 & 51.8 & 122 & 48.2 & 253 & 78.1 & \multirow[t]{2}{*}{7.179} & \multirow[t]{2}{*}{0.007} \\
\hline Non-Saudi & 24 & 33.8 & 47 & 66.2 & 71 & 21.9 & & \\
\hline \multicolumn{9}{|l|}{ Occupation } \\
\hline Physician & 34 & 54 & 29 & 46 & 63 & 19 & \multirow{3}{*}{1.75} & \multirow{3}{*}{0.417} \\
\hline Nurse & 84 & 48 & 91 & 52 & 175 & 54 & & \\
\hline Others & 37 & 43 & 49 & 57 & 86 & 27 & & \\
\hline \multicolumn{9}{|l|}{ Shift time } \\
\hline Morning & 17 & 40.5 & 25 & 59.5 & 42 & 13 & \multirow[t]{2}{*}{1.048} & \multirow[t]{2}{*}{0.306} \\
\hline Alternate & 138 & 48.9 & 144 & 51.1 & 282 & 87 & & \\
\hline No. of coworkers & & & & & & & & \\
\hline$\leq 10$ & 124 & 53.4 & 108 & 46.6 & 232 & 71.6 & 10.3 & 0.001 \\
\hline$>10$ & 31 & 33.7 & 61 & 66.3 & 92 & 28.4 & & \\
\hline Report encouragement & & & & & & & & \\
\hline Yes & 76 & 39.4 & 117 & 60.6 & 193 & 59.6 & 13.69 & $<0.001$ \\
\hline No & 79 & 60.3 & 52 & 39.7 & 131 & 40.4 & & \\
\hline System availability & & & & & & & & \\
\hline Yes & 98 & 43.6 & 127 & 56.4 & 225 & 69.4 & 5.41 & 0.02 \\
\hline No & 57 & 57.6 & 42 & 42.4 & 99 & 30.6 & & \\
\hline
\end{tabular}

$\mathrm{SD}=$ standard deviation

\section{Logistic regression analysis of workplace violence}

After entering sex, nationality, number of coworkers, lack of report encouragement and system availability into the regression model, the only independent variables significantly associated with general violence were lack of report encouragement and Saudi nationality (Table 5). For physical violence, the only significant independent factor was male sex. Lack of report encouragement was the only variable that remained significantly associated with verbal abuse and bullying.

\section{Discussion}

The main aim of this study was to estimate the prevalence of workplace violence in a sample of 324 participants working in EDs in 4 public hospitals in Dammam, Saudi Arabia. The study showed that the prevalence of violence among HCWs was $47.8 \%$, which was considerably lower than $89.3 \%$ in nurses in the EDs in 3 public hospitals in Saudi Arabia (15). However, our result was closer to the prevalence of $57.5 \%$ in HCWs in 2 government hospitals and 10 primary healthcare centres in Saudi Arabia who experienced at least 1 violence incident (22), and similar to the prevalence of $45.6 \%$ among HCWs in 12 family medical centres in Riyadh (2).

Most studies have shown that psychological violence (especially verbal abuse) was higher than physical violence $(15,21,26)$. The number of incidents of verbal abuse was approximately 5 -fold that of the number of incidents of physical violence among nurses in several EDs in Jordan (10), which can be explained by the stress of acute illness experienced by patients and/or families at the time of the violent act. In the current study, verbal abuse formed $52 \%$ of the violent incidents, physical violence $19 \%$, bullying $16 \%$, racial harassment $10 \%$ and sexual harassment was the least common (3\%). Similarly, a study in Macau revealed incidents of verbal abuse (53.4\%), physical assault (16.1\%), bullying (14.2\%), sexual harassment (4.6\%) and racial harassment (2.6\%) among physicians and nurses (24). Verbal abuse was the most common form of violence because it was easy to perpetuate and could not be controlled by any sort of security measures. The 


\begin{tabular}{|c|c|c|c|c|c|c|c|}
\hline \multirow[t]{2}{*}{ Health-care worker characteristics } & \multicolumn{7}{|c|}{ Physical } \\
\hline & Yes & $\%$ & No & $\%$ & $\begin{array}{c}\text { Total } \\
324\end{array}$ & c2 & $\mathbf{P}$ \\
\hline \multicolumn{8}{|l|}{ Sex } \\
\hline Male & 22 & 20.2 & 87 & 79.8 & 109 & \multirow[t]{2}{*}{5.442} & \multirow[t]{2}{*}{0.02} \\
\hline Female & 23 & 10.7 & 192 & 89.3 & 215 & & \\
\hline \multicolumn{8}{|l|}{ No. of coworkers } \\
\hline$\leq 10$ & 38 & 16.4 & 194 & 83.6 & 232 & \multirow[t]{2}{*}{4.237} & \multirow[t]{2}{*}{0.04} \\
\hline \multirow[t]{2}{*}{$>10$} & 7 & 7.6 & 85 & 92.4 & 92 & & \\
\hline & \multicolumn{7}{|c|}{ Verbal } \\
\hline \multicolumn{8}{|l|}{ Sex } \\
\hline Male & 51 & 46.8 & 58 & 53.2 & 109 & \multirow[t]{2}{*}{4.314} & \multirow[t]{2}{*}{0.038} \\
\hline Female & 75 & 34.9 & 140 & 65.1 & 215 & & \\
\hline \multicolumn{8}{|l|}{ Nationality } \\
\hline Saudi & 106 & 41.9 & 147 & 58.1 & 253 & \multirow[t]{2}{*}{4.397} & \multirow[t]{2}{*}{0.036} \\
\hline Non-Saudi & 20 & 28.2 & 51 & 71.8 & 71 & & \\
\hline \multicolumn{8}{|l|}{ No. of coworkers } \\
\hline$\leq 10$ & 101 & 43.5 & 131 & 56.5 & 232 & \multirow[t]{2}{*}{7.420} & \multirow[t]{2}{*}{0.006} \\
\hline$>10$ & 25 & 27.2 & 67 & 72.8 & 92 & & \\
\hline \multicolumn{8}{|l|}{ Report encouragement } \\
\hline Yes & 61 & 31.6 & 132 & 68.4 & 193 & \multirow[t]{2}{*}{10.653} & \multirow[t]{2}{*}{0.001} \\
\hline \multirow[t]{2}{*}{ No } & 65 & 49.6 & 66 & 50.4 & 131 & & \\
\hline & \multicolumn{7}{|c|}{ Bullying } \\
\hline \multicolumn{8}{|l|}{ Report encouragement } \\
\hline Yes & 16 & 8.3 & 177 & 91.7 & 193 & \multirow[t]{2}{*}{6.329} & \multirow[t]{2}{*}{0.012} \\
\hline \multirow[t]{2}{*}{ No } & 23 & 17.6 & 108 & 82.4 & 131 & & \\
\hline & \multicolumn{7}{|c|}{ Sexual } \\
\hline \multicolumn{8}{|l|}{ Marital status } \\
\hline Married & 2 & 0.9 & 224 & 99.1 & 226 & & \multirow[t]{2}{*}{0.028} \\
\hline Unmarried & 5 & 5.1 & 93 & 94.9 & 98 & & \\
\hline
\end{tabular}

$S D=$ standard deviation.

majority (74.4\%) of bullying incidents occurred in the morning and managers were a major source (56.7\%) of incidents followed by staff members $(35.9 \%)$, which is often explained by the presence of most managerial staff in the morning. Moreover, interprofessional violence may have played a role in these incidents.

Most of the workplace violence was experienced by Saudi nationals, which is explained mainly by the high number of Saudi participants in the study. The majority of offenders were patients (42\%) followed by their relatives (31\%), which was similar to some previous studies $(2,15,20,25,26)$ but contrary to others $(1,14,23)$, in which the companions of the patients were the main offenders. The fact that patients were the major aggressors in the current study could be explained by the absence of deterrent action (63.9\%) towards violent incidents as supported by management in the workplaces, following the rule "the patient is always right".

Workplace violence had negative consequences on HCWs, such as reduced work performance (44.4\%), complaints against HCWs (8.3\%) and injuries (0.8\%), which is supported by previous studies $(1,2,18,19)$. Reduced work performance could be explained by feeling unsafe, anger, anxiety or distress or performing duties in an unprofessional way. Some previous studies suggested that the reasons for violence in EDs were staff shortage, absence of punishment, lack of security, and long waiting times for patients. Certain characteristics of HCWs, including age, sex, years of experience and marital status, have been associated with increased workplace violence $(27,28)$. In the current study, the frequency of physical violence was high among men (20.2\%) and sexual harassment was high among unmarried HCWs (5.1\%).

More than half of violent incidents $(66.7 \%)$ were not reported and the main reason was the feeling that reporting was useless. This could be related to the existing system that includes reporting the incident to a supervisor, duty director, or the police. Most HCWs ( $n=$ $57,57.6 \%$ ) exposed to workplace violence questioned the availability of a violence reporting system. Moreover, the majority $(75.9 \%)$ raised queries about the efficiency of the security measures applied in EDs of the studied hospitals. Our results could be explained by lack of awareness of the reporting systems and inefficient security measures. Hogarth et al. (29) noted that the solution agreed upon by HCWs to decrease workplace violence was encouragement by management to report violent incidents and to develop preventative measures.

The current study is one of few to cover all types of violence (physical and psychological, including verbal threats, bullying, and sexual and racial harassment) and used the standard WHO definition of violence. 


\begin{tabular}{|c|c|c|c|c|c|c|c|c|c|}
\hline \multirow[t]{2}{*}{ Variables } & & \multirow[t]{2}{*}{ B } & \multirow[t]{2}{*}{ SE } & \multirow[t]{2}{*}{$\begin{array}{l}\text { Wald } \\
\text { test }\end{array}$} & \multirow[t]{2}{*}{ df } & \multirow[t]{2}{*}{ Sig } & \multirow[t]{2}{*}{$\operatorname{Exp}(B)$} & \multicolumn{2}{|c|}{$\begin{array}{c}95 \% C I \\
\text { for } \operatorname{Exp}(B)\end{array}$} \\
\hline & & & & & & & & Lower & Upper \\
\hline General & $\begin{array}{l}\text { Saudi nationality } \\
\text { Lack of report encouragement } \\
\text { Constant }\end{array}$ & $\begin{array}{l}1.015 \\
-0.915 \\
-0.351\end{array}$ & $\begin{array}{l}0.438 \\
0.375 \\
0.723\end{array}$ & $\begin{array}{l}5.375 \\
5.945 \\
0.236\end{array}$ & $\begin{array}{l}1 \\
1 \\
1\end{array}$ & $\begin{array}{l}0.020 \\
0.015 \\
0.627\end{array}$ & $\begin{array}{l}2.759 \\
2.497 \\
0.704\end{array}$ & $\begin{array}{l}1.170 \\
1.197\end{array}$ & $\begin{array}{l}6.507 \\
5.209\end{array}$ \\
\hline Physical & $\begin{array}{l}\text { Male sex } \\
\text { Constant }\end{array}$ & $\begin{array}{l}1.045 \\
-2.380\end{array}$ & $\begin{array}{l}0.485 \\
0.331\end{array}$ & $\begin{array}{c}4.632 \\
51.824\end{array}$ & $\begin{array}{l}1 \\
1\end{array}$ & $\begin{array}{c}0.031 \\
<0.001\end{array}$ & $\begin{array}{l}2.842 \\
0.093\end{array}$ & 1.098 & 7.358 \\
\hline Verbal & $\begin{array}{l}\text { Lack of report encouragement } \\
\text { Constant }\end{array}$ & $\begin{array}{r}0.887 \\
-2.260\end{array}$ & $\begin{array}{l}0.425 \\
0.595\end{array}$ & $\begin{array}{c}4.350 \\
14.448\end{array}$ & $\begin{array}{l}1 \\
1\end{array}$ & $\begin{array}{c}0.037 \\
<0.001\end{array}$ & $\begin{array}{l}2.428 \\
0.104\end{array}$ & 1.055 & 5.589 \\
\hline Bullying & $\begin{array}{l}\text { Lack of report encouragement } \\
\text { Constant }\end{array}$ & $\begin{array}{r}0.857 \\
-3.260\end{array}$ & $\begin{array}{l}0.348 \\
0.570\end{array}$ & $\begin{array}{c}6.074 \\
32.676\end{array}$ & $\begin{array}{l}1 \\
1\end{array}$ & $\begin{array}{c}0.014 \\
<0.001\end{array}$ & $\begin{array}{l}2.356 \\
0.038\end{array}$ & 1.192 & 4.657 \\
\hline
\end{tabular}

$d f=$ degrees of freedom; $S E=$ standard error; Sig = significance.

Additionally, all HCWs in EDs of public hospitals were targeted. However, limitations cannot be excluded. The size of the sample may limit generalization of the results. The questionnaire was self-administered and recall bias could not be excluded, as in most similar surveys.

\section{Conclusions and recommendations}

In this study, workplace violence was prevalent among HCWs, and verbal abuse was the commonest type. The most important associated factor was absence of punish- ment, which was agreed upon by the majority of HCWs. Creation of an environment that encourages HCWs to report violent incidents and raising awareness of HCWs about violence reporting systems in EDs are recommended. Ensuring the reporting of all violent incidents and follow-up of the appropriate actions are essential. Supporting programmes to help and provide HCWs with the knowledge to manage and control incidents are needed.

Funding: None.

Competing interests: None declared.

\section{Violence au travail chez les agents de santé œuvrant dans les services d'urgence des hôpitaux publics de Dammam, en Arabie saoudite Résumé}

Contexte : La violence est un grave problème de santé au travail. Les agents de santé des services d'urgence sont particulièrement susceptibles d'être exposés à la violence et d'en subir les conséquences négatives sur le plan personnel.

Objectifs: La présente étude visait à estimer la prévalence de la violence au travail et des facteurs qui y sont potentiellement associés chez les agents de santé œuvrant dans les services d'urgence des hôpitaux publics de Dammam, en Arabie saoudite.

Méthodes : Une étude transversale a été menée d'août à octobre 2018 dans quatre services d'urgence d'hôpitaux publics relevant du ministère saoudien de la Santé. Les données ont été recueillies au moyen de questionnaires auto-administrés.

Résultats: Sur les 380 questionnaires distribués, 324 ont été renvoyés (taux de réponse de $85 \%$ ). Près des deux tiers des participants étaient des femmes $(66,4 \%)$ et plus de la moitié $(54 \%)$ étaient des infirmières. Au total, 155 agents de santé $(47,8 \%)$ ont subi au moins un type de violence au cours des 12 mois précédents. Sur l'ensemble des faits de violence signalés, 52 \% étaient des violences verbales et $19 \%$ des violences physiques. Le harcèlement sexuel (3\%) était le type de violence le moins fréquent. Le manque d'encouragement à signaler les actes de violence et la nationalité saoudienne étaient les seules variables significatives associées à la violence sur le lieu de travail.

Conclusions : La violence sur le lieu de travail est répandue. Les violences verbales sont les faits les plus fréquemment rapportés par les agents de santé œuvrant dans les services d'urgence des hôpitaux saoudiens. Pour améliorer la sécurité sur le lieu de travail, il est important d'encourager les agents de santé à signaler les faits de violence et de leur faire connaître les mécanismes qui leur permettent de le faire. 


$$
\begin{aligned}
& \text { العنف في أماكن العمل بين العاملين في مجال الرعاية الصحية في أقسام الطوارئ بالمستشفيات العامة في الدمام بالمملكة العربية السعودية } \\
& \text { موسى الحارثي، محمد عليان، حسن أبوجد، معتزة عبد الوهاب } \\
& \text { الخلاصة } \\
& \text { الخلفية: يُعد العنف في مكان العمل أحد مشاكل الصحة المهنية الخطيرة. ويواجه العاملون في مجال الرعاية الصحية الطارئة خطراً كبيراً للتعرُّض } \\
& \text { للعنف مع عو اقب شخصية سلبية. }
\end{aligned}
$$

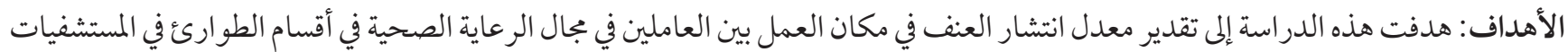

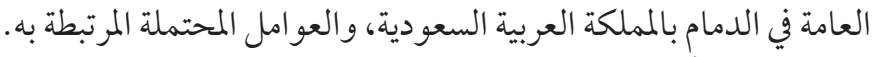

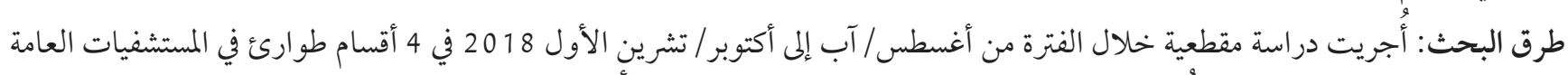

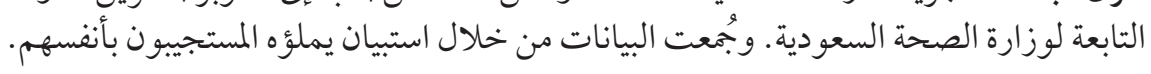

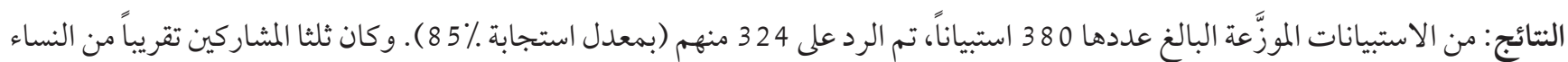

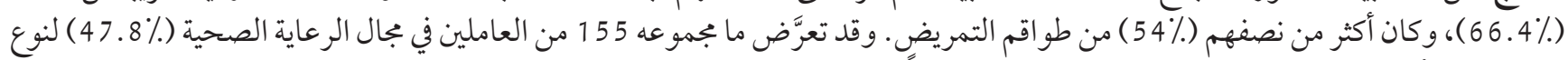

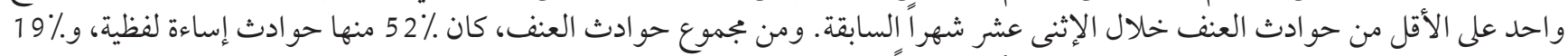

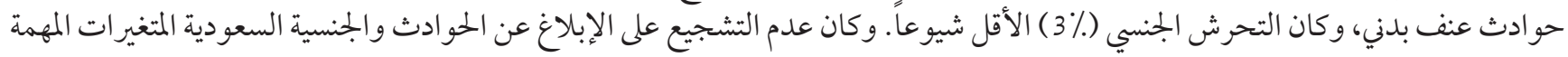

$$
\begin{aligned}
& \text { الوحيدة المرتبطة بالعنف في مكان بكان العمل. }
\end{aligned}
$$

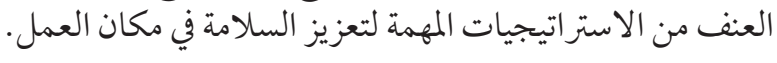

\section{References}

1. Alzahrani TY, Almutairi AH, Alamri DA, Alamri MM and Alalawi YS. Violence and aggression toward health care professionals in emergency departments in Tabuk, Saudi Arabia. Eur J Pharm Med Res. 2016,3(1):5-11. http://www.ejpmr.com/admin/download/ article/MTQ1MTUzODA3NS5wZGY

2. Al-Turki N, Afify AA and AlAteeq M. Violence against health workers in Family Medicine Centers. JMDH. 2016 May 31;9:257-66. https://www.ncbi.nlm.nih.gov/pubmed/27330300 PMID:27330300

3. Krug EG, Mercy JA, Dahlberg LL and Zwi AB. The world report on violence and health. The Lancet. 2002 Oct 5;360(9339):1083-8 https://www.ncbi.nlm.nih.gov/pubmed/12384003 PMID:12384003

4. Violence. Occupational hazards in hospitals. Cincinnati: National Institute for Occupational Safety and Health; 2002 (https:// www.cdc.gov/niosh/docs/2002-101/default.html, accessed 6 May 2020).

5. ILO, WHO. Joint program on workplace violence in the health sector, workplace violence in the health sector. Country case studies research instruments. Survey questionnaire. English. Geneva: International Labour Office, International Council of Nurses, World Health Organization, Public Services International; 2003 (https://www.who.int/violence_injury_prevention/violence/interpersonal/en/WVquestionnaire.pdf, accessed 6 May 2020).

6. Kansagra SM, Rao SR, Sullivan AF, Gordon JA, Magid DJ, Kaushal R, et al. A survey of workplace violence across 65 US emergency departments. Acad Emerg Med. 2008 Dec;15(12):1268-74. http://dx.doi.org/10.1111/j.1553-2712.2008.00282.x PMID:18976337

7. Fujita S, Ito S, Seto K, Kitazawa T, Matsumoto K and Hasegawa T. Risk factors of workplace violence at hospitals in Japan. J Hosp Med. 2012 Feb;7(2):79-84. http://dx.doi.org/10.1002/jhm.976 PMID:22058040

8. Fisekovic MB, Trajkovic GZ, Bjegovic-Mikanovic VM and Terzic-Supic ZJ. Does workplace violence exist in primary health care? Evidence from Serbia. Eur J Public Health. 2015 Aug;25(4):693-8. http://dx.doi.org/10.1093/eurpub/cku247 PMID:25644138

9. Esmaeilpour M, Salsali M and Ahmadi F. Workplace violence against Iranian nurses working in emergency departments. Int Nurs Rev. 2011 Mar;58(1):130-7. http://dx.doi.org/10.1111/j.1466-7657.2010.00834.x PMID:21281305

10. Albashtawy M. Workplace violence against nurses in emergency departments in Jordan. Int Nurs Rev. 2013 Dec 1;60(4):550-5. http://dx.doi.org/10.1111/inr.12059 PMID:24117233

11. Bayram B, Çetin M, Oray NÇ and Can İÖ. Workplace violence against physicians in Turkey's emergency departments: a cross-sectional survey. BMJ open. 2017 Jun 29;7(6):e013568. http://dx.doi.org/10.1136/bmjopen-2016-013568 PMID:28663323

12. El-Gilany AH, El-Wehady A and Amr M. Violence against primary health care workers in Al-Hassa, Saudi Arabia. JIV. 2010 Apr;25(4):716-34. http://dx.doi.org/10.1177/0886260509334395 PMID:19494243

13. Al-Shamlan NA, Jayaseeli N, Al-Shawi MM and Al-Joudi AS. Are nurses verbally abused? A cross-sectional study of nurses at a university hospital, Eastern Province, Saudi Arabia. J Family Community Med. 2017 Sep-Dec;24(3):173-80. http://dx.doi. org/10.4103/jfcm.JFCM_45_17 PMID:28932162 
14. Algwaiz WM and Alghanim SA. Violence exposure among health care professionals in Saudi public hospitals. A preliminary investigation. Saudi Med J. 2012 Jan;33(1):76-82. PMID:22273653

15. Alyaemni A and Alhudaithi H. Workplace violence against nurses in the emergency departments of three hospitals in Riyadh, Saudi Arabia: a cross-sectional survey. NursingPlus Open. 2016;2:35-41. https://doi.org/10.1016/j.npls.2016.09.001

16. Rehmani R. Emergency section and overcrowding in a university hospital of Karachi, Pakistan. JPMA. 2004 May;54(5):233-7. PMID:15270179

17. Abdellah RF and Salama KM. Prevalence and risk factors of workplace violence against health care workers in emergency department in Ismailia, Egypt. Pan Afr Med J. 2017 Jan 17;26:21. http://dx.doi.org/10.11604/pamj.2017.26.21.10837 PMID:28451000

18. Magnavita N and Heponiemi T. Violence towards health care workers in a Public Health Care Facility in Italy: a repeated cross-sectional study. BMC Health Serv Res. 2012Dec;12(1):108. http://dx.doi.org/10.1186/1472-6963-12-108 PMID:22551645

19. Kitaneh M and Hamdan M. Workplace violence against physicians and nurses in Palestinian public hospitals: a cross-sectional study. BMC Health Serv Res. 2012 Dec;12(1):469. https://bmchealthservres.biomedcentral.com/track/pdf/10.1186/1472-6963-12-469

20. Speroni KG, Fitch T, Dawson E, Dugan L and Atherton M. Incidence and cost of nurse workplace violence perpetrated by hospital patients or patient visitors. J Emerg Nurs. 2014 May;40(3):218-28. http://dx.doi.org/10.1016/j.jen.2013.05.014 PMID:24054728

21. Muzembo BA, Mbutshu LH, Ngatu NR, Malonga KF, Eitoku M, Hirota R, et al. Workplace violence towards Congolese health care workers: a survey of 436 healthcare facilities in Katanga province, Democratic Republic of Congo. J Occup Health. 2015;57(1):69-8o. http://dx.doi.org/10.1539/joh.14-0111-OA PMID:25476862

22. Alsaleem SA, Alsabaani A, Alamri RS, Hadi RA, Alkhayri MH, Badawi KK, et al. Violence towards healthcare workers: A study conducted in Abha City, Saudi Arabia. JFCM. 2018 Sep-Dec;25(3):188-93. http://dx.doi.org/10.4103/jfcm.JFCM_170_17 PMID:30220849

23. Vezyridis P, Samoutis A, Mavrikiou PM. Workplace violence against clinicians in Cypriot emergency departments: a national questionnaire survey. J Clin Nurs. 2015 May;24(9-10):1210-22. http://dx.doi.org/10.1111/jocn.12660 PMID:25047646

24. Cheung T, Lee PH and Yip PS. Workplace violence toward physicians and nurses: prevalence and correlates in Macau. Int J Environ Res Public Health. 2017 Aug 4;14(8). pii: E879. http://dx.doi.org/10.3390/ijerph14080879 PMID:28777333

25. Cheung T and Yip PS. Workplace violence towards nurses in Hong Kong: prevalence and correlates. BMC Public Health. 2017 Feb 14;17(1):196. http://dx.doi.org/10.1186/s12889-017-4112-3 PMID:28196499

26. Abbas MA, Fiala LA, Abdel Rahman AG and Fahim AE. Epidemiology of workplace violence against nursing staff in Ismailia Governorate, Egypt. J Egypt Public Health Assoc. 2010 Jan 1;85(1-2):29-43. PMID:21073846

27. Jmal-Hammami K, Loukil-Feki M, Moalla E, Gargouri I, Masmoudi ML, Marouen-Jamoussi S. Les agressions sur les lieux du travail en milieu hospitalier: À propos de 107 cas. Archives des Maladies Professionnelles et de l'Environnement. 2006 Sep 1;67(4):626-30. https://doi.org/10.1016/S1775-8785(06)70441-6

28. Gillespie GL, Gates DM, Miller M and Howard PK. Workplace violence in healthcare settings: risk factors and protective strategies. Rehabilitation nursing. 2010 Sep-Oct;35(5):177-84. http://dx.doi.org/10.1002/j.2048-7940.2010.tboo045.x PMID:20836482

29. Hogarth KM, Beattie J and Morphet J. Nurses' attitudes towards the reporting of violence in the emergency department. Australas Emerg Nurs J. 2016 May;19(2):75-81. http://dx.doi.org/10.1016/j.aenj.2015.03.006 PMID:26012889 